\title{
Copper(II) Schiff base complexes and their mixed thin layers with $\mathrm{ZnO}$ nanoparticles
}

\author{
MAGDALENA BARWIOLEK*, ROBERT SZCZESNY and EDWARD SZŁYK \\ Faculty of Chemistry, Nicolaus Copernicus University in Torun, 87-100 Torun, Poland \\ e-mail:mbarwiolek@umk.pl
}

MS received 3 March 2016; revised 4 May 2016; accepted 24 May 2016

\begin{abstract}
Cu}$ (II) complexes with Schiff bases derived from ethylenediamine (en) and 2-pyridinecarboxaldehyde (pyca), 2,5-dimethoxybenzaldehyde (dmbaH) or 4-imidazolecarboxaldehyde (4Him) were obtained and studied by elemental analysis, UV-VIS and IR spectra. Zinc oxide was synthesized using a simple homogeneous precipitation method with zinc acetate as a starting material. Thin layers of the studied $\mathrm{Cu}(\mathrm{II})$ complexes were deposited on $\mathrm{Si}(111)$ or $\mathrm{ZnO} / \mathrm{Si}(111)$ substrates by a spin coating method and characterized with a scanning electron microscopy (SEM/EDS), atomic force microscopy (AFM) and fluorescence spectroscopy. For $\mathrm{Cu}$ (II) layers the most intensive fluorescence bands due to intra-ligand transitions were observed between 462 and $503 \mathrm{~nm}$. The fluorescence intensity of thin layers was corelated to the rotation speed. In the case of the $\left[\mathrm{Cu}(\mathrm{II})\left(\mathrm{en}(4 \mathrm{Him})_{2}\right) \mathrm{Cl}_{2}\right](\mathbf{2 a}) / \mathrm{ZnO} / \mathrm{Si}$ and $\left[\mathrm{Cu}\left(\mathrm{en}(\mathrm{dmbaH})_{2}\right) \mathrm{Cl}_{2}\right](\mathbf{3 a}) / \mathrm{ZnO} / \mathrm{Si}$ layers the quenching of the emission band from $\mathrm{ZnO}$ at $440 \mathrm{~nm}\left(\lambda_{\mathrm{ex}}=330 \mathrm{~nm}\right)$ associated with various intrinsic or extrinsic lattice defects was noted.
\end{abstract}

Keywords. Thin layer; $\mathrm{ZnO}$ nanoparticles; copper complexes; AFM; SEM; fluorescence.

\section{Introduction}

Study of copper(II) complexes of Schiff bases and nitrogen donor ligands has become a focal point of interest for researchers in recent times, not only for their varied structural features, but also for their potential application in various fields. ${ }^{1-5}$ These compounds are also known for their biological role and fluorescence properties. For instance, the copper(II) complexes with Schiff bases derived from trans $( \pm$ )cyclohexanediamine and 2-pyridinecarboxaldehyde exhibited luminescence properties in the solution and in the solid state. ${ }^{6}$ The $\mathrm{Cu}$ (II) complexes $[\mathrm{Cu}(\mathrm{II})(\mathrm{L})]\left(\mathrm{CF}_{3} \mathrm{SO}_{3}\right)_{2}$, where $\mathrm{L}$ is a ligand obtained from cyclohexanediamine or ethylenediamine and aldehydes e.g., 2-quinolinecarboxaldehyde, 6-methyl-2-pyridinecarboxaldehyde or 2-thiazolecarboxaldehyde can be used as molecular memories for the wet chemical computers. ${ }^{7}$ Furthermore, Schiff base derivatives incorporating a fluorescent moiety are a useful tool for optical sensing of metal ions. Thin organic and organometallic films have attracted research interest due to their technologically important optical and electronic properties. ${ }^{8}$ These materials exhibit luminescence; they are used as conductors, semi-conductors and organic light emitting diodes (OLED) ${ }^{9-11}$ Many

*For correspondence thin films of metal complexes, such as $\mathrm{Zn}(\mathrm{II}), \mathrm{Pt}(\mathrm{II})$, $\mathrm{Cu}(\mathrm{II})$ or $\mathrm{Ag}(\mathrm{I})$ with Schiff bases (e.g., N,N'-bis(salicyli dene)-1,2-ethylenediamine, bis(2-(2-hydroxyphenyl) benzothiazole) were synthetised and their luminescence properties have been employed in organic optoelectronics. $^{12-15}$

The thin organic-inorganic layers of different metal compounds were obtained by many different methods e.g., laser ablation, cathodoluminescence or spin coating. ${ }^{16-19}$ However, there are only a few reports on copper(II) complexes in materials obtained by spin coating method. For example, $\left.\left[\mathrm{Cu}_{3} \text { (opba)(pmdta) }\right)_{2}\right]$ $\left(\mathrm{NO}_{3}\right)_{2}(\mathrm{pmdta}=1,1,4,7,7$-pentamethyl-diethylenetriamine, opba $=$ orthophenylenebis(oxamato)) complex was used to get thin layer of $\mathrm{Cu}$ (II) complex on $\mathrm{SiO}_{2} / \mathrm{Si}^{10}$ This technique was also used for deposition of $\left[\left(n \mathrm{Bu}_{3} \mathrm{P}\right)_{3} \mathrm{Cu}-\mathrm{O}_{2} \mathrm{CCH}_{2} \mathrm{CO}_{2}-\mathrm{Cu}\left(\mathrm{P} n \mathrm{Bu}_{3}\right)_{3}\right]$ and $\left[\left(n \mathrm{Bu}_{3} \mathrm{P}\right)_{3} \mathrm{Cu}-\mathrm{O}_{2} \mathrm{C}\left(\mathrm{CH}_{2}\right)_{2} \mathrm{CO}_{2}-\mathrm{Cu}\left(\mathrm{P} n \mathrm{Bu}_{3}\right)_{3}\right]$ on $\mathrm{SiO}_{2} /$ $\mathrm{TiN} / \mathrm{Cu}$ substrate. The layers were then heated up to $450^{\circ} \mathrm{C}$, and the result of this process was the conversion of complexes to $\mathrm{CuO}$ by decomposition. ${ }^{20}$ In this case, SEM results showed incomplete homogeneous layers and defects in the surface structure. This was explained by the different film thicknesses obtained during the spin coating process, which upon heating produced defects due to unequal evaporation leading to partially cracked copper oxide films. These 
results showed the spin coating as a promising method for deposition of thin and homogeneous layers of transition metal complexes. Previously, copper(II) and nickel(II) complexes with optically active Schiff bases derived from $(1 R, 2 R)(-)$ cyclohexanediamine or 2-(2aminoethyl)pyridine were deposited by us on silicon or glass using the spin coating method. ${ }^{21-23}$ The obtained thin materials exhibited fluorescence, which depends on the spin coating parameters and the molecular structure of the complexes.

It is also known, that the $\mathrm{ZnO}$ layers can be obtained by sputtering processes, pulsed laser deposition technique or by chemical methods such as, microemulsion, hydrothermal, sol-gel and precipitation followed by the deposition of nanoparticle suspensions using wet coating methods. ${ }^{24-28}$ Those materials were also used in optical technology. Moreover, the deposited $\mathrm{ZnO}$ nanopowders ${ }^{29,30}$ and $\mathrm{ZnO}$ nanoparticles doped by different metal ions such as, manganese ${ }^{31}$ or copper exhibited photoluminescence bands, and the emission intensity increased with increase in doping up to a certain percentage of $\mathrm{Cu}^{2+}(5 \%){ }^{32,33}$

The advantages of using wet coating method are two-fold: First, the layers can be formed by subsequent or simultaneous deposition of different materials. Second, use of spin coating offers the opportunity for facile fabrication of a uniformly dispersed nanoparticles or/and solutions onto the substrates even for large areas, and well-defined thickness of films in mild conditions. Therefore, this type of deposition method allows to fabricate a wide variety of composite materials. The facts mentioned above: the fluorescence properties of the Schiff bases and their complexes, the possibility of using the spin coating technique for deposition of the copper(II) complexes and $\mathrm{ZnO}$ nanoparticles on different substrates and the likely fluorescence behavior of the obtained layers, prompted us to synthesize a series of new copper(II) complexes with Schiff bases derived from ethylenediamine and several aldehydes. These complexes were characterized spectroscopically and their fluorescence properties were also studied.

In this article, we would like to report how a simple and efficient method as spin coating can be utilized to produce composite films using both nanoparticle dispersions and solutions of complexes. Moreover, the aim of the study was to investigate the microstructural and spectroscopic properties of obtained layers. Therefore, the new copper(II) complexes were used as precursors of thin layers in the spin coating technique. In addition, the zinc oxide and the $\mathrm{Cu}(\mathrm{II})$ complexes layers doped with $\mathrm{ZnO}$ nanopowder were obtained. The morphology and homogeneity of the layers were analyzed by AFM and SEM microscopy, and the fluorescence properties of the layers were studied. The mechanical properties of some layers induced by microindentation were investigated as well.

\section{Experimental}

\subsection{Materials and methods}

The ethylenediamine (en) (99\%), 2-pyridinecarboxaldehyde (99\%) (pyca), 2,5-dimethoxybenzaldehyde (dmbaH) (99\%), 4-imidazolecarboxaldehyde (4Him) (98\%) and ethylene glycol (EG) (99\%) were purchased from Aldrich. $\mathrm{CuCl}_{2} \cdot 2 \mathrm{H}_{2} \mathrm{O}, \mathrm{Cu}\left(\mathrm{OOCCH}_{3}\right)_{2} \cdot \mathrm{H}_{2} \mathrm{O}$ and $\mathrm{Zn}\left(\mathrm{OOCCH}_{3}\right)_{2} \cdot 2 \mathrm{H}_{2} \mathrm{O}$ were purchased from POCh Gliwice. All reagents were used without further purification.

Infrared spectra were recorded on a Perkin Elmer SPECTRUM 2000 spectrophotometer. UV-Vis absorption spectra were recorded on a Milton Roy Spectronic 1201 spectrophotometer in $\mathrm{CH}_{3} \mathrm{CN}\left(1 \times 10^{-5} \mathrm{M}\right)$ solution. IR spectra were performed on a Spectrum 2000 Perkin/Elmer FT IR using KBr discs in the range 400$4000 \mathrm{~cm}^{-1}$ and polyethylene IR sample cards in the range $400-20 \mathrm{~cm}^{-1}$. 13C CPMAS NMR and ${ }^{1} \mathrm{H},{ }^{13} \mathrm{C}$, ${ }^{15} \mathrm{~N}$ NMR spectra were collected with Bruker AMX 300 spectrometer $(300 \mathrm{MHz})$ in $\mathrm{CDCl}_{3}$ against TMS. The fluorescence spectra were recorded on a spectrofluorometer F-7000 HITACHI in the range 900-200 nm $\left(5 \times 10^{-4} \mathrm{~mol} \mathrm{dm}^{-3} \mathrm{MeCN}\right.$ solution or silicon slides $)$ Elemental analyses were carried out using a Elementar Gmbh Vario Macro CHN analyzer. The films were deposited on $\mathrm{Si}(111)$ wafers $(10 \backslash 10 \mathrm{~mm}) \sim 500 \mathrm{um}$ thick using spin coating technique. Precursors were dissolved in tetrahydrofuran and deposited on $\mathrm{Si}(111)$ (900-2000 rpm/30 s-600 s; drying $5000 \mathrm{rpm} / 200 \mathrm{~s}, 1 \times$ $10^{-3} \mathrm{M}$ in THF) using a Laurell 650SZ spin coater. Zinc oxide layers were obtained from ethanol suspension $\left(1.2 \mathrm{mg} / \mathrm{cm}^{3}\right)$ by the same method. A suspension of $\mathrm{ZnO}$ was spun onto the substrate at $1000-5000 \mathrm{rpm}$ for 20-360 s and each plate was subsequently dried at a rotation speed of $5000 \mathrm{rpm}$ for $20 \mathrm{~s}$.

The morphology and composition of the obtained materials were analyzed with a scanning electron microscopy (SEM) LEO Electron Microscopy Ltd, England, model 1430 VP equipped with detectors of secondary electrons (SE) and energy dispersive X-ray spectrometer (EDS) Quantax with detector XFlash 4010 (Bruker AXS microanalysis $\mathrm{GmbH}$ ). The atomic force microscopy AFM studies in the tapping mode were performed on Veeco (Digital Instrument) microscope Type: MultiMode NanoScope IIIa. Powder X-ray diffraction (PXD) analysis was performed using a 
Philips (Almelo, The Netherlands) XPERT $\theta-2 \theta$ diffractometer with $\mathrm{CuK} \alpha$ radiation. The indentation properties of the layers were made on NHT2 microindentation tester (TTX-NHT) from Anton Paar TriTec SA with a Berkovich indenter using loads 20 and $100 \mathrm{mN}$ and holding time of $5 \mathrm{~s}$. The system hardness and elastic modulus were determined from the indentation curves by the standard Oliver and Pharr method. ${ }^{34}$

\subsection{Synthesis}

2.2a Synthesis of en (pyca) $)_{2}$ (1): Ethylenediamine (en) $(60 \mu \mathrm{L}, 1 \mathrm{mmol})$ in EtOH was added to pyridine2 -carboxaldehyde (pyca) $(190 \mu \mathrm{L}, 2 \mathrm{mmol})$. The mixture was stirred under reflux for $2 \mathrm{~h}$. The orange precipitate formed was recrystallized from ethanol. (82.7\% yield). ${ }^{1} \mathrm{H}$ NMR [ppm]: $\delta 8.62$ (d, $2 \mathrm{H}$, arom.), $8.42(\mathrm{~s}, 2 \mathrm{H}, \mathrm{CH}=\mathrm{N}), 7.98(\mathrm{~d}, 2 \mathrm{H}$, arom. $), 7.73(2 \mathrm{H}$, arom.), 7.30 (ddd, 2H, arom.), 4.07 (s, 4H, $-\mathrm{CH}_{2}-$ ). ${ }^{13} \mathrm{C}$ NMR $[\mathrm{ppm}]: \delta 163.4 \mathrm{C} 2,154.4 \mathrm{C} 3,149.4 \mathrm{C} 7$, $136.5 \mathrm{C} 5,124.7 \mathrm{C} 6,121.3 \mathrm{C} 4,61.3 \mathrm{C} 1\left(\mathrm{CH}_{2}\right) .{ }^{15} \mathrm{~N}$ NMR [ppm]: $-42.5 \mathrm{~N}(1),-67.3 \mathrm{CH}=\mathrm{N}$. IR $(\mathrm{KBr}$, $\left.\mathrm{cm}^{-1}\right):$ 3010-3070s $v(\mathrm{C}-\mathrm{HAr}), 2922,2853 \mathrm{~s} v(\mathrm{CH})$, $1645 \mathrm{~m} v(\mathrm{C}=\mathrm{N}), 1584 \mathrm{~s} v(\mathrm{C}-\mathrm{N}), 1434 \mathrm{~m} v(\mathrm{C}=\mathrm{C}) .{ }^{6,35-40}$ (vs, very strong; s, strong; m, medium; w, weak, vw ver weak) (figure 1).

UV-visible in MeCN $\left[\lambda_{\max } / \mathrm{nm}\left(\varepsilon /\left[\mathrm{dm}^{3} \cdot \mathrm{mol}^{-1} \cdot \mathrm{cm}^{-1}\right]\right)\right]$ 235(37520), 267(38120), 319(25326).

2.2b Synthesis of en(4Him) $)_{2}$ (2): (92.1\% yield, (60 $\mu \mathrm{L}, 1 \mathrm{mmol}$ en, $0.1922 \mathrm{~g}, 2 \mathrm{mmol} 4 \mathrm{Him}) .{ }^{13} \mathrm{C} \mathrm{CP}$ MAS NMR [ppm]: $\delta 156.1 \mathrm{C} 2,139.4 \mathrm{C} 5,128.6 \mathrm{C} 3$, $123.6 \mathrm{C} 4,62.2 \mathrm{C} 1\left(\mathrm{CH}_{2}\right)$. IR $\left(\mathrm{KBr}, \mathrm{cm}^{-1}\right)$ : 3436w $v(\mathrm{~N}-\mathrm{H}), 2913-3032 \mathrm{w} v(-\mathrm{CH}), 1648 \mathrm{vs} v(\mathrm{C}=\mathrm{N}), 1512 \mathrm{~s}$ $v(\mathrm{C}-\mathrm{N}), 1450 \mathrm{vs}, 1472 \mathrm{~m} v(\mathrm{C}=\mathrm{C}) .^{6,35-37,41} \mathrm{UV}$-visible in $\mathrm{MeCN}\left[\lambda_{\max } / \mathrm{nm}\left(\varepsilon /\left[\mathrm{dm}^{3} \cdot \mathrm{mol}^{-1} \cdot \mathrm{cm}^{-1}\right]\right)\right] 273(31520)$, 318(16437) (figure 1).

2.2c Synthesis of en $(\text { dmbaH })_{2}$ (3): yield (92.2\%, $60 \mu \mathrm{L}, 1 \mathrm{mmol}$ en, $0.3323 \mathrm{~g}, 2 \mathrm{mmol} 4 \mathrm{Him} .{ }^{1} \mathrm{H}$ NMR [ppm]: $\delta 8.71(\mathrm{~s}, 2 \mathrm{H}, \mathrm{CH}=\mathrm{N}), 7.51(\mathrm{~d}, 2 \mathrm{H}), 6.95$ $(\mathrm{dd}, 2 \mathrm{H}), 6.85(\mathrm{~d}, 2 \mathrm{H}), 3.99\left(\mathrm{~s}, 4 \mathrm{H},-\mathrm{CH}_{2}-\right), 3.82$ (s, 6H) $3.79(\mathrm{~s}, 6 \mathrm{H}){ }^{13} \mathrm{C}$ NMR $[\mathrm{ppm}]: \delta 158.6 \mathrm{C} 2$, $153.8 \mathrm{C} 5,153.4(\mathrm{C} 8), 125.3 \mathrm{C} 3,118.6 \mathrm{C} 6,112.7$ $\mathrm{C} 7,110.6 \mathrm{C} 4,61.9 \mathrm{C} 1\left(\mathrm{CH}_{2}\right), 56.3 \mathrm{C} 10\left(\mathrm{OCH}_{3}\right), 55.8$ $\mathrm{C} 9\left(\mathrm{OCH}_{3}\right) .{ }^{15} \mathrm{~N}$ NMR $[\mathrm{ppm}]:-69.6-\mathrm{CH}=\mathrm{N}$. IR $(\mathrm{KBr}$, $\mathrm{cm}^{-1}$ ): 3309 vs $v(\mathrm{~N}-\mathrm{H}), 3009-3064 \mathrm{~m} v(\mathrm{C}-\mathrm{HAr}), 2906$, 2831s $v(\mathrm{CH}), 1637 \mathrm{vs} v(\mathrm{C}=\mathrm{N}), 1582 \mathrm{~s} v(\mathrm{C}-\mathrm{N}), 1427 \mathrm{~s}$, 1496s $v(\mathrm{C}=\mathrm{C}), 1303 \mathrm{~s} v(\mathrm{Ph}-\mathrm{O}) .^{36,37,42,43} \mathrm{UV}$-visible in $\mathrm{MeCN}\left[\lambda_{\max } / \mathrm{nm}\left(\varepsilon /\left[\mathrm{dm}^{3} \cdot \mathrm{mol}^{-1} \cdot \mathrm{cm}^{-1}\right]\right)\right] 222(49732)$, 251(29946), 332(15508) (figure 1).

\subsection{Synthesis of the Cu(II) complexes}

2.3a $\left[\mathrm{Cu}\left(\right.\right.$ en $\left.\left.(\text { pyca })_{2}\right) \mathrm{Cl}_{2}\right]$ (1a): Ethanolic solution of $\mathrm{CuCl}_{2} \times 2 \mathrm{H}_{2} \mathrm{O}(0.0287 \mathrm{~g}, 0.16 \mathrm{mmol}$ in $40 \mathrm{~mL}$ ethanol $)$ was added to en $(\text { pyca })_{2}(\mathbf{1})(0.0396 \mathrm{~g}(0.16 \mathrm{mmol})$ in $\mathrm{EtOH}$. The reaction mixture was stirred at $25^{\circ} \mathrm{C}$ for $4 \mathrm{~h}$, then, the solvent was removed under reduced pressure and a dark green solid was isolated. $\left[\mathrm{Cu}\left(\right.\right.$ en $\left.\left.(\text { pyca })_{2}\right) \mathrm{Cl}_{2}\right]$ (1a) (Yield 72.8\%) Analysis: Calculated for $\mathrm{C}_{14} \mathrm{H}_{14} \mathrm{~N}_{4} \mathrm{Cl}_{2} \mathrm{Cu}$ : $\mathrm{Cu}$ 17.04, $\mathrm{C}$ 45.11, $\mathrm{H}$ 3.78, N 15.03. Found: $\mathrm{Cu} 16.61, \mathrm{C} 45.48, \mathrm{H} 4.11, \mathrm{~N}$ 15.34 [\%]. IR $\left(\mathrm{KBr}, \mathrm{cm}^{-1}\right): 3386 \mathrm{~m} v(\mathrm{~N}-\mathrm{H}), 3068 \mathrm{~m}$ $v(\mathrm{C}=\mathrm{CH}), 2922 \mathrm{~m} v(\mathrm{C}-\mathrm{H}), 1604 \mathrm{vs} v(\mathrm{C}=\mathrm{N}), 1569 \mathrm{~m}$ $v(\mathrm{C}-\mathrm{N}), 1447 \mathrm{~s} v(\mathrm{C}=\mathrm{C}), 303 \mathrm{~s} v(\mathrm{Cu}-\mathrm{Cl}), 422 \mathrm{~s} v(\mathrm{Cu}-$ N). ${ }^{37} \mathrm{UV}$-visible in $\mathrm{MeCN}\left[\lambda_{\max } / \mathrm{nm}\left(\varepsilon /\left[\mathrm{dm}^{3} \cdot \mathrm{mol}^{-1}\right.\right.\right.$. $\mathrm{cm}^{-1}$ )] 255(8461), 320(2307).

In the same way $\left[\mathrm{Cu}\left(\mathrm{en}(\text { pyca })_{2}\right)\left(\mathrm{OOCCH}_{3}\right)_{2}\right](\mathbf{1 b})$, $\left[\mathrm{Cu}\left(\mathrm{en}(4 \mathrm{Him})_{2}\right) \mathrm{Cl}_{2}\right]$ (2a) and $\left[\mathrm{Cu}\left(\mathrm{en}(\mathrm{dmbaH})_{2}\right) \mathrm{Cl}_{2}\right]$ (3a) were synthesized (figure 1).

$2.3 \mathrm{~b} \quad\left[\mathrm{Cu}\left(\right.\right.$ en $\left.\left.(\text { pyca })_{2}\right)\left(\mathrm{OOCCH}_{3}\right)_{2}\right](\mathbf{1 b}):(79.2 \%$ yield,

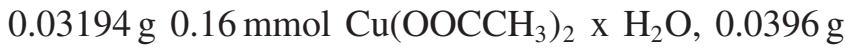
$0.16 \mathrm{mmol}$ en(pyca) $)_{2}$. Analysis: Calculated for $\mathrm{C}_{18} \mathrm{H}_{20} \mathrm{~N}_{4} \mathrm{O}_{4} \mathrm{Cu}: \mathrm{Cu}$ 15.13, C 51.48, $\mathrm{H}$ 4.80, N 13.34; Found: $\mathrm{Cu}$ 15.19, C 51.68, H 4.29, N 13.04 [\%]. IR $\left(\mathrm{KBr}, \mathrm{cm}^{-1}\right): 3422 \mathrm{~m} v(\mathrm{OH}), 3074 \mathrm{w} v(\mathrm{C}=\mathrm{CH}), 1598 \mathrm{vs}$ $v(\mathrm{C}=\mathrm{N}), 1547 \mathrm{vw} \quad v(\mathrm{C}-\mathrm{N}), 1444 \mathrm{~m} \quad v(\mathrm{C}=\mathrm{C}), 1710 \mathrm{~s}$ $v_{\mathrm{asCOO}^{-}}, 1476 \mathrm{~m} v_{\mathrm{sCOO}^{-}}, 1292 \mathrm{~m} v(\mathrm{C}-\mathrm{O}), 92 \mathrm{w} 4 \delta(\mathrm{O}-\mathrm{H})$, $550 \mathrm{~m} v(\mathrm{Cu}-\mathrm{O}), 454 \mathrm{~m} v(\mathrm{Cu}-\mathrm{N}){ }^{6,7,36,37,44} \mathrm{UV}$-visible in $\mathrm{MeCN}\left[\lambda_{\max } / \mathrm{nm}\left(\varepsilon /\left[\mathrm{dm}^{3} \cdot \mathrm{mol}^{-1} \cdot \mathrm{cm}^{-1}\right]\right)\right] 210(37795)$, 252(6299), 326(1574).

2.3c $\quad\left[\mathrm{Cu}\left(\right.\right.$ en $\left.\left(4 \mathrm{Him}_{2}\right) \mathrm{Cl}_{2}\right] \quad(\mathbf{2 a}): \quad(84.50 \%$ yield, $\mathrm{CuCl}_{2} \times 2 \mathrm{H}_{2} \mathrm{O} \quad 0.0287 \mathrm{~g}, \quad 0.16 \mathrm{mmol}, \quad 0.03459 \mathrm{~g}$, $0.16 \mathrm{mmol}$ en $\left.(4 \mathrm{Him})_{2}\right)$. Analysis: Calculated for $\mathrm{C}_{10} \mathrm{H}_{12} \mathrm{~N}_{6} \mathrm{Cl}_{2} \mathrm{Cu}: \mathrm{Cu} 18.12$, C 34.24, H 3.44, N 23.96; Found: $\mathrm{Cu} 18.13, \mathrm{C} 34.48, \mathrm{H} 3.12$, N 23.71 [\%]. IR $\left(\mathrm{KBr}, \mathrm{cm}^{-1}\right): 3422 \mathrm{~m} v(\mathrm{~N}-\mathrm{H}), 2931 \mathrm{w}, 2853 \mathrm{~m} v(\mathrm{CH})$, $1635 v s \quad v(\mathrm{C}=\mathrm{N}), 1508 \mathrm{w} \quad v(\mathrm{C}-\mathrm{N}), 1438 \mathrm{~s} \quad v(\mathrm{C}=\mathrm{C})$, $313 \mathrm{~m} v(\mathrm{Cu}-\mathrm{Cl}), 458 \mathrm{w} v(\mathrm{Cu}-\mathrm{N}){ }^{42,45}$ UV-visible in $\mathrm{MeCN}\left[\lambda_{\max } / \mathrm{nm}\left(\varepsilon /\left[\mathrm{dm}^{3} \cdot \mathrm{mol}^{-1} \cdot \mathrm{cm}^{-1}\right]\right)\right] 264(9122)$, 322(1403).

2.3d $\quad\left[\mathrm{Cu}\left(\mathrm{en}(\mathrm{dmbaH})_{2}\right) \mathrm{Cl}_{2}\right] \quad$ (3a): $\quad(76.4 \%$ yield, $\mathrm{CuCl}_{2} \quad \mathrm{x} \quad 2 \mathrm{H}_{2} \mathrm{O} \quad 0.0287 \mathrm{~g}, \quad 0.16 \mathrm{mmol}, 0.05702 \mathrm{~g}$, $\left.0.16 \mathrm{mmol} \mathrm{en}(\mathrm{dmbaH})_{2}\right)$. Analysis: Calculated for $\mathrm{C}_{20} \mathrm{H}_{24} \mathrm{~N}_{2} \mathrm{O}_{4} \mathrm{Cl}_{2} \mathrm{Cu}$ : Cu 12.94, C 48.93, H 3.92, N 5.70; Found: Cu 13.36, C 48.64, H 4.02, N 5.39 [\%]. IR (KBr, $\mathrm{cm}^{-1}$ ): 3307vs $v(\mathrm{~N}-\mathrm{H}), 3009-3064 v s v(\mathrm{C}-\mathrm{HAr}), 2953$, 2967vs $v(\mathrm{CH}), 1654 \mathrm{vs} v(\mathrm{C}=\mathrm{N}), 1587 \mathrm{vs} v(\mathrm{C}-\mathrm{N}), 1453 \mathrm{~s}$, 1496s $v(\mathrm{C}=\mathrm{C}), 477 \mathrm{w} v(\mathrm{Cu}-\mathrm{N}), 373 \mathrm{~s} v(\mathrm{Cu}-\mathrm{Cl}){ }^{6,34}$ 


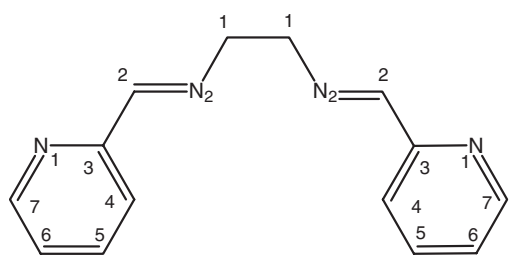

(1)

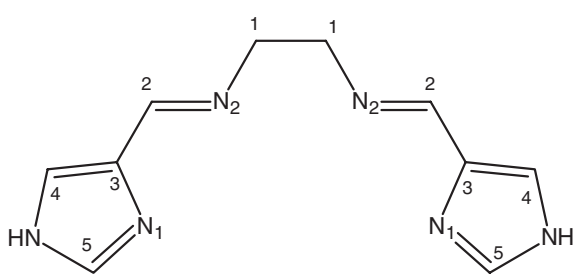

(2)

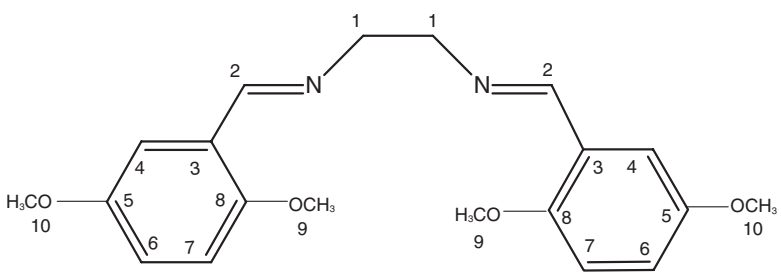

(3)

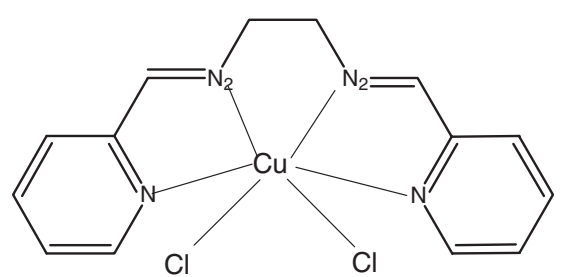

(1a)<smiles>Clc1nc(CN2CCN3CCN(Cc4c[nH]cn4)CC32)c[nH]1</smiles>

(2a)

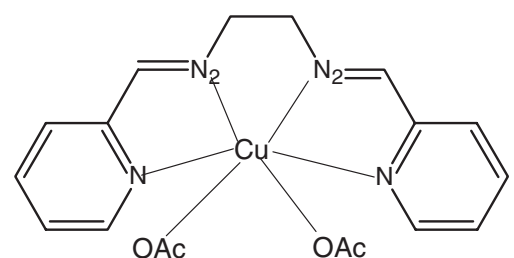

(1b)<smiles></smiles>

(3a)

Figure 1. Structures of en(pyca $)_{2}$ (1), en(4Him $)_{2}$ (2) and en(dmbaH $)_{2}$ (3) ligands and copper(II) complexes: [Cu(en(pyca $\left.\left.)_{2}\right) \mathrm{Cl}_{2}\right]$ (1a), $\left[\mathrm{Cu}\left(\mathrm{en}(\text { pyca })_{2}\right)\left(\mathrm{OOCCH}_{3}\right)_{2}\right]$ (1) $)$, $\left[\mathrm{Cu}\left(\mathrm{en}(4 \mathrm{Him})_{2}\right) \mathrm{Cl}_{2}\right](\mathbf{2 a})$ and $\left[\mathrm{Cu}\left(\mathrm{en}(\mathrm{dmbaH})_{2}\right) \mathrm{Cl}_{2}\right](\mathbf{3 a})$.

$\mathrm{UV}$-visible in $\mathrm{MeCN}\left[\lambda_{\max } / \mathrm{nm}\left(\varepsilon /\left[\mathrm{dm}^{3} \cdot \mathrm{mol}^{-1} \cdot \mathrm{cm}^{-1}\right]\right)\right]$ 211(45098), 251(18627), 350(3921).

\subsection{Synthesis of $\mathrm{ZnO}$ nanoparticles}

In a typical synthesis procedure, $\mathrm{Zn}\left(\mathrm{OOCCH}_{3}\right)_{2} \cdot 2 \mathrm{H}_{2} \mathrm{O}$ $(0.649 \mathrm{~g}, 3 \mathrm{mmol})$ and urea $(0.995 \mathrm{~g}, 9 \mathrm{mmol})$ were added to water/EG solution $(1: 8 \mathrm{v} / \mathrm{v}, 75 \mathrm{~mL})$ and kept under stirring solutions at $25^{\circ} \mathrm{C}$ until a homogeneous solution was obtained. The resultant solution was heated to $90^{\circ} \mathrm{C}$. The conditions were kept for $1.5 \mathrm{~h}$ and then the mixture was cooled to room temperature. The resulting white precipitate was washed and centrifuged at $9000 \mathrm{rpm}$ with water, acetone and ethanol. Table 1 shows the different experimental condition applied for $\mathrm{ZnO}$ preparation.

Table 1. Experimental conditions for $\mathrm{ZnO}$ synthesis.

\begin{tabular}{lccc}
\hline Sample & $\mathrm{R}$ & $\mathrm{T}\left({ }^{\circ} \mathrm{C}\right)$ & Time $(\mathrm{h})$ \\
\hline A1 & $6: 1$ & 90 & 1.5 \\
A2 & $3: 1$ & 70 & 1.5 \\
A3 & $3: 1$ & 70 & 3 \\
A4 & $3: 1$ & 90 & 1.5 \\
A5 & $1: 1$ & 90 & 1.5 \\
A6 & $4: 1$ & 90 & 1.5 \\
\hline
\end{tabular}

$\mathrm{R}=$ urea/ $\mathrm{Zn}{ }^{2+}$ molar ratio. 


\section{Results and Discussion}

\subsection{Infrared spectroscopy}

The band from stretching vibrations of the $-\mathrm{C}=\mathrm{N}$ group, characteristic of the Schiff base, appeared in the region between 1637 and $1648 \mathrm{~cm}^{-1}$. The band of $v(\mathrm{C}=\mathrm{N})$ vibrations are shifted by $13-41 \mathrm{~cm}^{-1}$ in the spectra of copper(II) complexes towards lower frequencies, as a result of $\mathrm{Cu}$ (II) coordination with the ligand via the azomethine group. ${ }^{6,45}$ In the IR spectrum of $\left[\mathrm{Cu}\left(\mathrm{en}(\text { pyca })_{2}\right)\left(\mathrm{OOCCH}_{3}\right)_{2}\right](\mathbf{1 b})$ bands at 1475 and $1711 \mathrm{~cm}^{-1}$ due to symmetrical and asymmetrical stretching vibrations of acetate ion were observed. ${ }^{44-48}$ In (1b) the monodentate coordination of $\mathrm{CH}_{3} \mathrm{COO}^{-}$anion was noted. The similar type of coordination was observed for the copper(II) complex with en(pyca) and $\mathrm{CF}_{3} \mathrm{SO}_{3}$ ions ${ }^{7}$ or $\mathrm{Cu}(\mathrm{II})$ and trans $( \pm) \operatorname{chxn}\left(\right.$ pyca). ${ }^{6}$ Furthermore, in the spectra of (1a), (2a) and (3a), the band between 303 and $373 \mathrm{~cm}^{-1}$ are present due to the stretching vibration of the $\mathrm{Cu}$ $\mathrm{Cl}$ in these complexes. ${ }^{48}$ Additionally, in the IR spectrum of $\left[\mathrm{Cu}\left(\mathrm{en}(\text { pyca })_{2}\right)\left(\mathrm{OOCCH}_{3}\right)_{2}\right](\mathbf{1 b})$, the band from $\mathrm{Cu}-\mathrm{O}$ vibration at $550 \mathrm{~cm}^{-1}$ was observed. Moreover, because of the coordination via nitrogen, bands from $\mathrm{Cu}-\mathrm{N}$ vibrations appeared in the $422-477 \mathrm{~cm}^{-1}$ regions in the spectra of all complexes. ${ }^{6,48}$ Similar way of coordination was already observed by us in the copper(II) complexes with Schiff bases derived from 2-(2-pyridyl)ethylamine. ${ }^{23}$

The shift of the bands from stretching vibrations of the azomethine group in all the compounds and the presence of specific bands of the $\mathrm{Cu}-\mathrm{Cl}$ or $\mathrm{COO}_{\text {asym }}^{-} /$sym vibrations in the spectra of particular complexes indicated the correctness of the proposed coordination sphere.

\subsection{Electronic absorption spectra}

All ligands exhibit intense absorption bands between 222 and $273 \mathrm{~nm}$ assigned to intraligand $\pi \rightarrow \pi^{*}$ transition in imidazole or phenolate moieties. ${ }^{38,49}$ Moreover, the most characteristic band derived from $\pi \rightarrow \pi^{*}$ transition in the azomethine group appeared at $319 \mathrm{~nm}$ for (1), $318 \mathrm{~nm}$ for (2) and $332 \mathrm{~nm}$ for (3). The UV-Vis spectra of the complexes showed absorption between 320-350 nm, which can be attributed to a LMCT transitions. Additionally, in the spectra of the complexes, the band from intraligand $\pi \rightarrow \pi^{*}$ transition in imidazole and phenolate shifted and appeared between $210 \mathrm{~nm}$ and $264 \mathrm{~nm}$.

\subsection{ZnO nanoparticles characterization}

The results (figure 2) demonstrated the presence of particles with different particle sizes and shapes, depending on the precipitation conditions. The most homogeneous material with the smallest particle size (sample A4) was stick-like in shape with widths of $40 \mathrm{~nm}$ and lengths of $100 \mathrm{~nm}$ (figure 2a). The other crystallites reach the size of few hundred nanometers (figure $2 \mathrm{a}, \mathrm{c}$ ). The XRD patterns of powders show a full set of diffraction peaks of hexagonal wurtzite structure (JCPDS 36-1451; figure 3a). These data were also confirmed by IR spectra of the prepared samples. A strong band at $422 \mathrm{~cm}^{-1}$ with a visible shoulder at $554 \mathrm{~cm}^{-1}$ corresponding with $\mathrm{Zn}-\mathrm{O}$ vibrational mode was observed (figure $3 \mathrm{~b}$ ). ${ }^{50}$ Moreover, infrared spectroscopy confirms the presence of functional groups at the surface of $\mathrm{ZnO}$ particles. The broad absorption peaks at $3384 \mathrm{~cm}^{-1}$ and $2957 / 2925 / 2853 \mathrm{~cm}^{-1}$ are attributed to stretching vibrations of $-\mathrm{OH}$ or $-\mathrm{NH}$ groups and the $\mathrm{CH}$ stretching, respectively. ${ }^{51}$ The bands at 1585 and $885 \mathrm{~cm}^{-1}$ are ascribed to in and out of plane of $\mathrm{O}$ $\mathrm{H}$ and $\mathrm{C}=\mathrm{O}$ stretching vibration. ${ }^{52,53}$ The absorbance peaks at 1420, 1064 and $1037 \mathrm{~cm}^{-1}$ in $\mathrm{ZnO}$ can be ascribed to $\mathrm{C}-\mathrm{O}$ vibration and $\mathrm{C}-\mathrm{H}$ bending modes. The small bands at 2371 and $2341 \mathrm{~cm}^{-1}$ may arise from the absorption of carbon dioxide.

\subsection{Thin films of Cu complexes}

The SEM images of the $\mathrm{Cu}$ (II) complex layers showed a uniform distribution of the compounds on the silicon
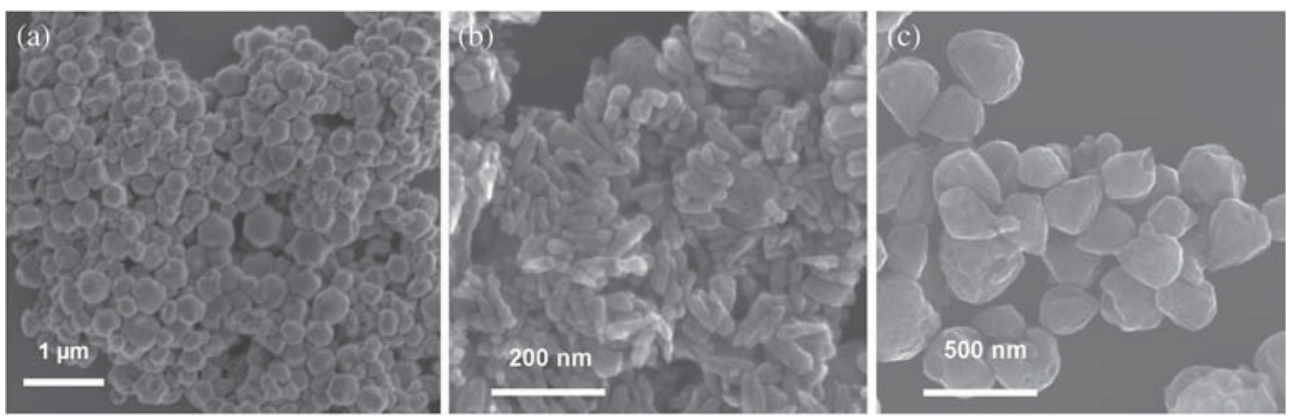

Figure 2. SEM micrographs of $\mathrm{ZnO}$ powders: a) sample A1, b) sample A4, c) sample A5. 


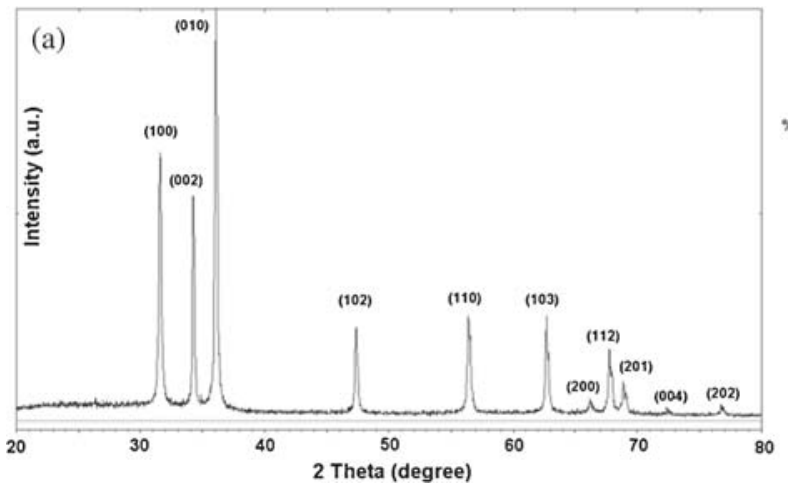

(b)

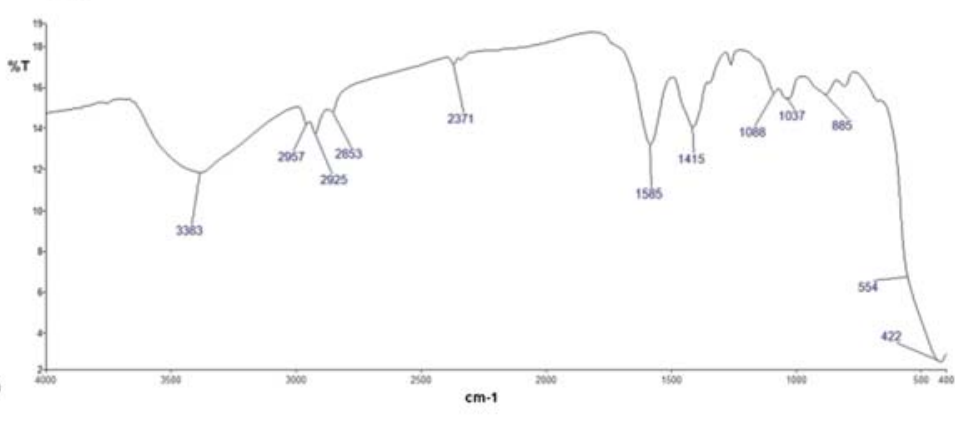

Figure 3. (a) XRD pattern of sample A4 and (b) IR spectra of sample A6.

surface. The layers were amorphous, but small crystallites appeared in some places due to incomplete solidification of the complex solution during the spin coating process, as previously reported. ${ }^{20,54}$

In the case of $\left.\mathrm{Cu}\left(\mathrm{en}(\text { pyca })_{2}\right) \mathrm{Cl}_{2}\right] \quad(\mathbf{1 a}) / \mathrm{Si}$ and $\left[\mathrm{Cu}\left(\mathrm{en}(\mathrm{dmbaH})_{2}\right) \mathrm{Cl}_{2}\right](\mathbf{3 a}) / \mathrm{Si}$ materials, the whole silicon surface was covered regularly with copper complexes $(900,1100$ and $2000 \mathrm{rpm} / \mathrm{min}(\mathbf{1 a}) / \mathrm{Si}$ and 1000 , 1100 and $2000 \mathrm{rpm} / \mathrm{min}(\mathbf{3 a}) / \mathrm{Si})$. The EDS results confirmed the presence of copper $(0.45 \%$ - $900 \mathrm{rpm}, 0.71 \%$ - $1000 \mathrm{rpm}$ and $0.47 \%-1100 \mathrm{rpm})$ in all (1a)/Si layers. Whereas, the $\left[\mathrm{Cu}\left(\mathrm{en}(4 \mathrm{Him})_{2}\right) \mathrm{Cl}_{2}\right](\mathbf{2 a}) / \mathrm{Si}$ material exhibited the highest copper content $(3.11 \%)$ when spin rate $2000 \mathrm{rpm}$ was set.

The SEM/EDS analysis of $\left[\mathrm{Cu}\left(\mathrm{en}(\mathrm{pyca})_{2}\right)\left(\mathrm{OOCCH}_{3}\right)_{2}\right]$ (1b)/Si(111) showed the evenly distributed complex on the silicon surface. The copper content was the biggest $(1.44 \%)$ when spin rate was set at $1100 \mathrm{rpm}$. Additionally, some crystallites were observed. The layers of (1b)/Si obtained at the other spin speeds $(900,1000$ and $2000 \mathrm{rpm}$ ) exhibited lowest copper content (about $0.5 \%$ ). Moreover, in these cases, the discontinuity of the materials (1000 and $2000 \mathrm{rpm}$ ) was noted.

For the $\left[\mathrm{Cu}\left(\mathrm{en}(\text { pyca })_{2}\right)\left(\mathrm{OOCCH}_{3}\right)_{2}\right](\mathbf{1 b}) / \mathrm{Si}$ and $[\mathrm{Cu}$ $\left(\right.$ en $\left.\left.(\text { pyca })_{2}\right) \mathrm{Cl}_{2}\right](\mathbf{1 a}) / \mathrm{Si}$ layers, the surface roughness $\left(\mathrm{R}_{\mathrm{q}}\right.$ - the root mean square roughness) was the highest when the speed was set at $900 \mathrm{rpm}(39.3 \mathrm{~nm})$ for $(\mathbf{1 a}) / \mathrm{Si}$ or $1100 \mathrm{rpm}(12 \mathrm{~nm})$ for $(\mathbf{1 b}) / \mathrm{Si}$. Increasing the spin speed to $2000 \mathrm{rpm}$ resulted in a lowering of the surface roughness, giving a relatively smooth material $\left(\mathrm{R}_{\mathrm{q}}=\right.$ $14.7 \mathrm{~nm}$ for (1a) and $7.26 \mathrm{~nm}$ for (1) $)$ ). Reducing the rotation speed gave a layer of $(\mathbf{1 b}) / \mathrm{Si}$ with some structures sticking out of the surface. Additionally, the latter materials were irregularly covered by the compound.

Similar to the $(\mathbf{1 b}) / \mathrm{Si}$ and $(\mathbf{1 a}) / \mathrm{Si}$ materials, the lowest roughness of $\left[\mathrm{Cu}\left(\mathrm{en}(4 \mathrm{Him})_{2}\right) \mathrm{Cl}_{2}\right](\mathbf{2 a}) / \mathrm{Si}$ was observed at the spin speed of $2000 \mathrm{rpm}\left(\mathrm{R}_{\mathrm{q}}=25.8 \mathrm{~nm}\right)$. The complex was evenly spread on the $\mathrm{Si}(111)$ substrate. While, in contrast to $(\mathbf{1 b}) / \mathrm{Si}$ and $(\mathbf{1 a}) / \mathrm{Si}$, in (2a)/Si lowering the spin speed did not cause important changes in the surface roughness. In the case of $\left[\mathrm{Cu}\left(\mathrm{en}(\mathrm{dmbaH})_{2}\right) \mathrm{Cl}_{2}\right](\mathbf{3 a}) / \mathrm{Si}$, the AFM analysis showed that complex (3a) is evenly arranged on Si substrate (figure 4). The compound formed islands of different heights, resulting in a flat surface $\left(R_{q}=19.5 \mathrm{~nm}\right.$, $1000 \mathrm{rpm})$. However, empty spaces in the surface were observed, which indicated layer discontinuity. Other spin speeds led to materials of the lowest roughness and uniform layers.

The above results suggest that the quality of the layer (uniformity, roughness) can be optimized by the variation of spin speed. In conclusion, layers obtained with

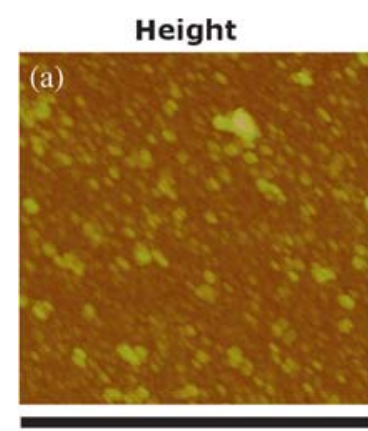

$5 \mathbf{\mu m}$

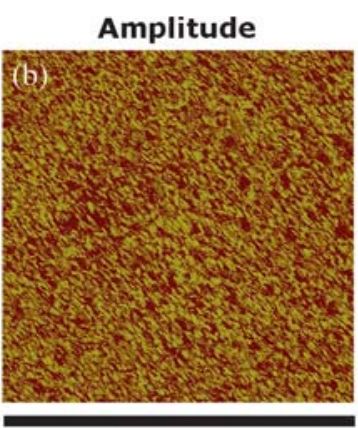

$5 \mu \mathrm{m}$

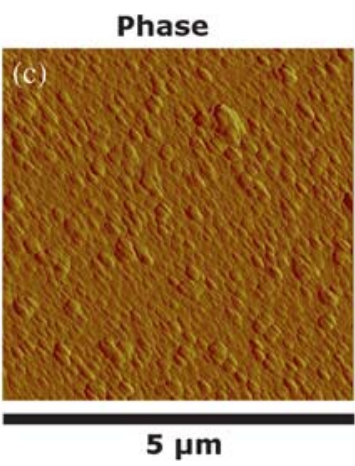

$5 \mu \mathrm{m}$

Figure 4. $\mathrm{AFM}$ images of $\left[\mathrm{Cu}\left(\mathrm{en}(\mathrm{dmbaH})_{2}\right) \mathrm{Cl}_{2}\right](\mathbf{3 a}) / \mathrm{Si}(1000 \mathrm{rpm}$, time $30 \mathrm{~s})$. 

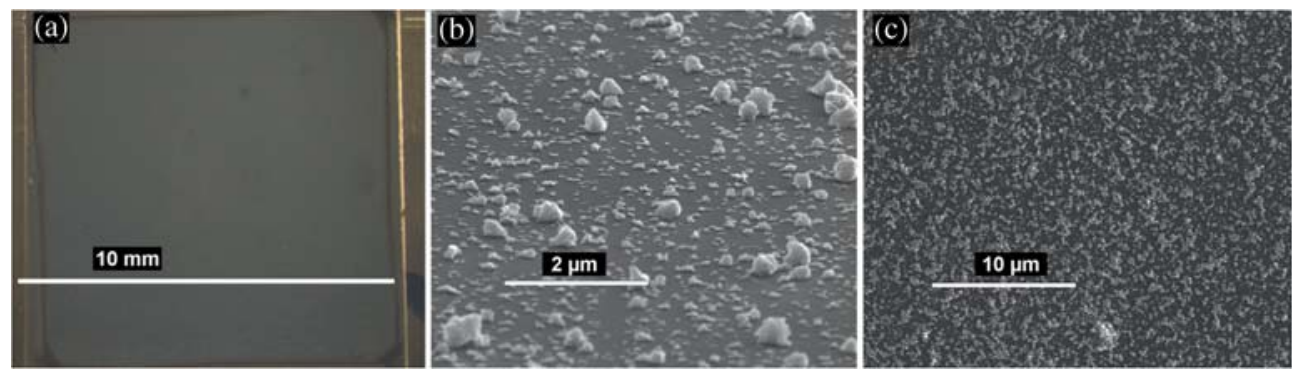

Figure 5. The $\mathrm{ZnO}$ layers: (a) optical microscopy and (b: cross-section) SEM images of sample A4 (3000 rpm, 3 min); (c) SEM image of sample A6 (5000 rpm, 3 min).

spin coating method are, in general, thin and homogeneous with complexes uniformly spread over the substrate surface.

The best parameters for the spin coating process which provide smooth, thin and homogeneous copper(II) materials with complexes uniformly spread over the substrate surface were: spin speed of 900,1100 or $2000 \mathrm{rpm}$ for $30 \mathrm{~s}$ depending on the precursor used. The layers reveal that the total thickness of film does not exceed $100 \mathrm{~nm}$.

\section{$3.5\left[\mathrm{Cu}\left(\mathrm{en}(4 \mathrm{Him})_{2}\right) \mathrm{Cl}_{2}\right](2 \mathrm{a}) / \mathrm{ZnO} / \mathrm{Si}$ and $\left[\mathrm{Cu}\left(\mathrm{en}(\mathrm{dmbaH})_{2}\right) \mathrm{Cl}_{2}\right](3 \mathrm{a}) / \mathrm{ZnO} / \mathrm{Si}$ thin films}

The zinc oxide layers were examined by optical microscopy (OM), SEM and AFM. In most cases, we observed uniform coated surfaces (figure 5a,c). It was noticed that the inorganic material was deposited both as separate grains and agglomerates composed of several nanoparticles (figure 5b). The AFM analysis of sample A4 layers reveals that the total thickness of film does not exceed $500 \mathrm{~nm}$.

In the case of the mixed layers, the copper complex and $\mathrm{ZnO}$ form aggregates and grains which pointed to porous nature of the layer (figure $6 a, b$ ). The total thickness of the layer does not exceed $700 \mathrm{~nm}$. The mapping analysis indicated uniformly deposited copper complex and $\mathrm{ZnO}$ on the silicon surface (figure 6c). Similar situation for layers of complexes was observed. ${ }^{55}$ Spin coated thin films of $\mathrm{Cu}, \mathrm{Co}, \mathrm{Ni}$ or $\mathrm{Pb}$ complexes with different tetraazaporphyrine derivatives on glass or quartz substrates had also shown porous structures with disordered array of island aggregation and thickness between 40 and $250 \mathrm{~nm} .{ }^{56-58}$ Those films, because of their porous nature, showed gas sensing behavior. Summarizing, the multistage coating process allows obtaining thin, uniform copper complex-zinc oxide mixed layers.

\subsection{Fluorescence properties of layers}

The fluorescence properties of the prepared layers were studied. $\left[\mathrm{Cu}\left(\mathrm{en}(\text { pyca })_{2}\right) \mathrm{Cl}_{2}\right] \quad(\mathbf{1 a}) / \mathrm{Si}, \quad\left[\mathrm{Cu}\left(\mathrm{en}(\text { pyca })_{2}\right)\right.$ $\left.\left(\mathrm{OOCCH}_{3}\right)_{2}\right](\mathbf{1 b}) / \mathrm{Si}$ and $\left[\mathrm{Cu}\left(\mathrm{en}(\mathrm{dmbaH})_{2}\right) \mathrm{Cl}_{2}\right](\mathbf{3 a}) / \mathrm{Si}$ materials exhibited the highest fluorescence intensity between 472 and $503 \mathrm{~nm}$ from intraligand $\pi \rightarrow \pi^{*}$ transitions $\left(\lambda_{\mathrm{ex}}=382 \mathrm{~nm}\right)$. The highest-intensity of emission band was noted for layers with relatively low roughness $(1100 \mathrm{rpm}$ for $(\mathbf{1 a}) / \mathrm{Si}$ and $900 \mathrm{rpm}$ for $(\mathbf{1 b}) / \mathrm{Si})$. Similar behavior was registered by us for layers of copper(II) complexes with Schiff bases derived from 2-(2-aminoethyl)pyridine. ${ }^{23}$ Materials formed with $\left[\mathrm{Cu}\left(\mathrm{en}(4 \mathrm{Him})_{2}\right) \mathrm{Cl}_{2}\right](\mathbf{2 a}) / \mathrm{Si}$ were excited at $365 \mathrm{~nm}$. In all cases, the emission from intraligand $\pi \rightarrow \pi^{*}$ transitions at $462 \mathrm{~nm}$ was observed. A substantially higher intensity of the fluorescence band for (2a) was registered for layer obtained at $1000 \mathrm{rpm}$. The above results indicate that the copper layers exhibit emission and that uniformly distributed film on substrate increases the emission band intensity.
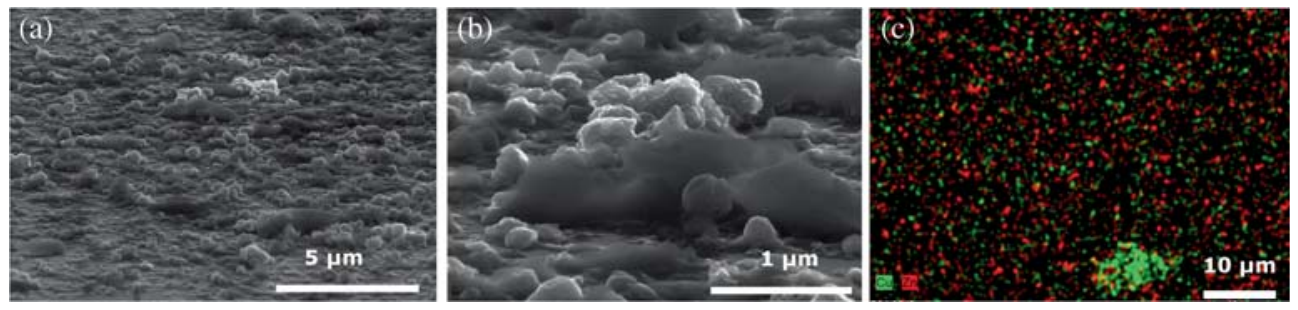

Figure 6. The SEM/EDS analysis of $\left[\mathrm{Cu}(\mathrm{II})\left((\mathrm{en})(4 \mathrm{Him})_{2}\right) \mathrm{Cl}_{2}\right](\mathbf{2 a}) / \mathrm{ZnO} / \mathrm{Si}: \mathrm{SEM}(\mathrm{a}, \mathrm{b}$; cross-section); EDS mapping (c) $(\mathrm{Cu}$ - green and $\mathrm{Zn}$ - red areas). 
The fluorescence properties of mixed copper complex/ZnO/Si films were studied as well. It is known that $\mathrm{ZnO}$ nanoparticles and the Schiff bases exhibit photoluminescence (PL) $)^{32,59}$ and have varied optical applications. ${ }^{33}$ In the PL spectrum of $\mathrm{ZnO}$, typically there are emission bands in the UV and visible regions. ${ }^{60}$ The PL spectrum of $\mathrm{ZnO}$ nanorods excited at $320 \mathrm{~nm}$ showed two UV emission bands at $356 \mathrm{~nm}$ and $382 \mathrm{~nm}$. The emission peak at $356 \mathrm{~nm}$ may be attributed to the band gap luminescence as it is blue shifted compared to the optical absorption. The nearband edge (NBE) emission peak at $382 \mathrm{~nm}$ is assigned to the recombination of free excitons. ${ }^{61}$ In addition, a broad shoulder in the range 400-425 nm and very weak defect-related blue emissions at 445, 453 and $470 \mathrm{~nm}$ also appeared. Blue emission bands in $\mathrm{ZnO}$ nanostructures were also reported ${ }^{62-65}$ which are associated with various intrinsic or extrinsic lattice defects. In order to check the influence of the copper complexes on the $\mathrm{PL}$ properties of the $\mathrm{ZnO}$ layer, the emission spectra of $\mathrm{ZnO} / \mathrm{Si},\left[\mathrm{Cu}\left(\mathrm{en}(4 \mathrm{Him})_{2}\right) \mathrm{Cl}_{2}\right](\mathbf{2 a}) / \mathrm{ZnO} / \mathrm{Si},[\mathrm{Cu}$ $\left.\left(\mathrm{en}(\mathrm{dmbaH})_{2}\right) \mathrm{Cl}_{2}\right](\mathbf{3 a}) / \mathrm{ZnO} / \mathrm{Si},\left[\mathrm{Cu}\left(\mathrm{en}(\mathrm{dmbaH})_{2}\right) \mathrm{Cl}_{2}\right]$ (3a) $/ \mathrm{Si}$, and $\left[\mathrm{Cu}\left(\mathrm{en}(4 \mathrm{Him})_{2}\right) \mathrm{Cl}_{2}\right](\mathbf{2 a}) / \mathrm{Si}$ were recorded. The intensity of the fluorescence band was the lowest for the copper(II) complex/Si layers. On the other hand, the highest intensity of the emission band was exhibited by the $\mathrm{ZnO} / \mathrm{Si}$ film. For the $\mathrm{ZnO}$ nanopowder layers mixed with copper(II) complexes [Cu(II)(en $\left.\left.(4 \mathrm{Him})_{2}\right) \mathrm{Cl}_{2}\right](\mathbf{2 a}) / \mathrm{ZnO} / \mathrm{Si}$ and $\left[\mathrm{Cu}\left(\mathrm{en}(\mathrm{dmbaH})_{2}\right) \mathrm{Cl}_{2}\right]$ (3a) $/ \mathrm{ZnO} / \mathrm{Si}$, quenching of the $\mathrm{PL}$ band of $\mathrm{ZnO}$ at $440 \mathrm{~nm}$ was observed $\left(\lambda_{\mathrm{ex}}=330 \mathrm{~nm}\right.$, figure 7$)$. Additionally, because of the low intensity of the

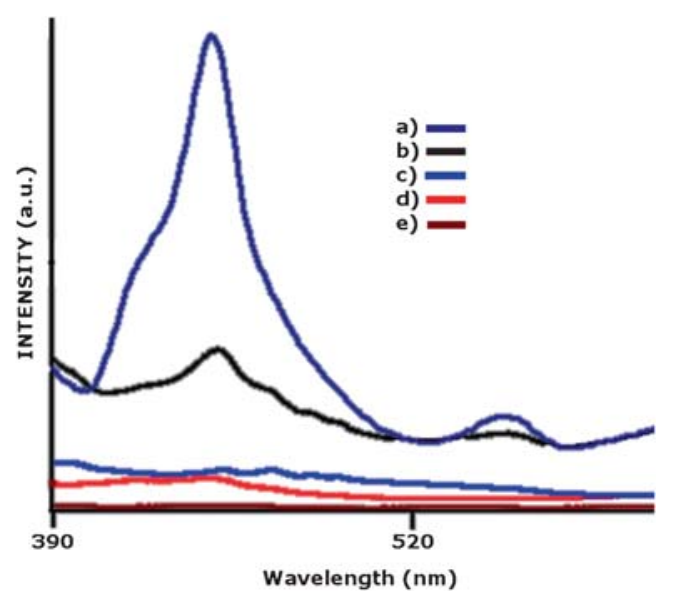

Figure 7. The photoluminescence spectra of (a) $\mathrm{ZnO} / \mathrm{Si}$ (2000 rpm, $3 \mathrm{~min})$, (b) $\left[\mathrm{Cu}\left(\mathrm{en}(4 \mathrm{Him})_{2}\right) \mathrm{Cl}_{2}\right] \quad(\mathbf{2 a}) / \mathrm{ZnO} / \mathrm{Si}$ (1500 rpm, $1 \mathrm{~min} / 3000 \mathrm{rpm}, 3 \mathrm{~min})$, (c) $\left[\mathrm{Cu}\left(\mathrm{en}(\mathrm{dmbaH})_{2}\right)\right.$ $\mathrm{Cl}_{2}$ ] (3a) $/ \mathrm{ZnO} / \mathrm{Si} \quad(2000 \mathrm{rpm}, 10 \mathrm{~min} / 3000 \mathrm{rpm}, 3 \mathrm{~min})$, (d) $\left[\mathrm{Cu}\left(\mathrm{en}(\mathrm{dmbaH})_{2}\right) \mathrm{Cl}_{2}\right](\mathbf{3 a}) / \mathrm{Si} \quad(4000 \mathrm{rpm}, 10 \mathrm{~min})$, (e) $\left[\mathrm{Cu}\left(\mathrm{en}(4 \mathrm{Him})_{2}\right) \mathrm{Cl}_{2}\right](\mathbf{2 a}) / \mathrm{Si}(1500 \mathrm{rpm}, 5 \mathrm{~min})$. fluorescence, a band coming from Rayleigh scattering at $659 \mathrm{~nm}$ and $649 \mathrm{~nm}$ for [Cu(II)((en) $\left.\left.(4 \mathrm{Him})_{2}\right) \mathrm{Cl}_{2}\right]$ (2a) $/ \mathrm{ZnO} / \mathrm{Si}$ and $\left[\mathrm{Cu}\left(\mathrm{en}(\mathrm{dmbaH})_{2}\right) \mathrm{Cl}_{2}\right](\mathbf{3 a}) / \mathrm{ZnO} / \mathrm{Si}$, respectively, were registered. ${ }^{66}$ The quenching of fluorescence by $\mathrm{Cu}$ (II) ion can be explained by process such as magnetic perturbation or redox activity. ${ }^{67-69}$

\subsection{The indentation of the layers}

Preliminary indentations were performed on uncoated silicon substrates $(\mathrm{Si}(100)), \mathrm{Cu}($ complex $) / \mathrm{Si}$ and $\mathrm{Cu}($ complex)/ZnO (A4)/Si wafers (figure 8). The calculated indentation hardness (HIT) and the indentation modulus (EIT) for silicon ranged from 10.754 to $11.561 \mathrm{GPa}$ and from 172.20 to $191.4 \mathrm{GPa}$, respectively, depending on the maximal load and loading rate values. The obtained values correspond well with comparable literature data. ${ }^{70,71}$ In the case of fabricated layers, the elastic modulus was, in general, similar to silicon substrate while hardness values were apparently lower than that for $\operatorname{Si}(111)$. Moreover, we observed a significant decrease of both mechanical parameters for samples deposited at lower rotation speed coexisting with longer deposition times (samples I and IV). The application of such coating parameters resulted in thicker layers, which obviously had serve impact on the mechanical properties of our composites. Additionally, the characteristic for monocrystalline silicon the popout phenomenon, which appeared during unloading for most measurements, was observed. ${ }^{72}$ It may be related to a substantial effect of the substrate on the overall hardness measure. In general, the hardness response

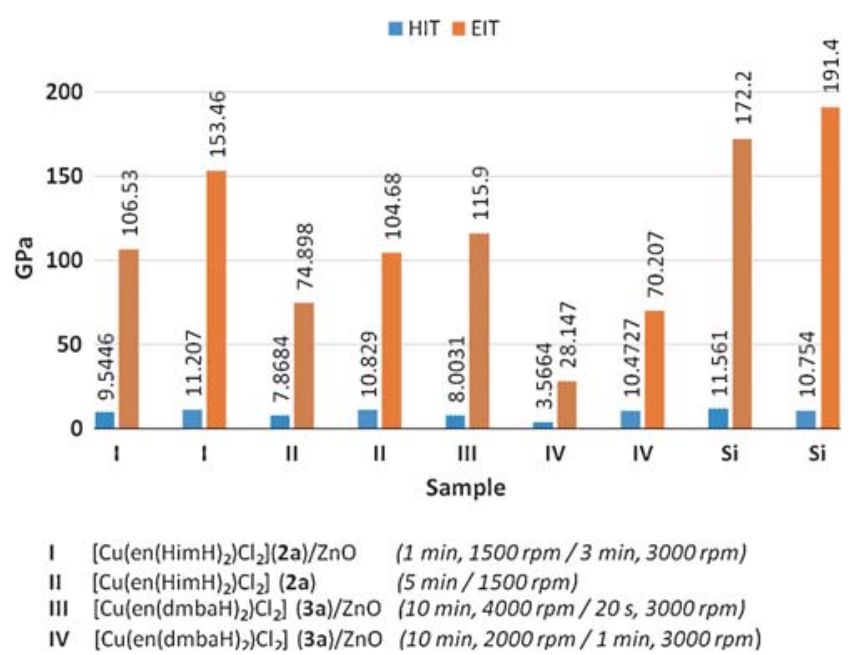

Figure 8. The hardness (HIT) and elastic modulus (EIT) values of fabricated layers registered under the following conditions: loading rate $200 \mathrm{mN} / \mathrm{min}$, max. load $100 \mathrm{mN}$ (dotted bars) and loading rate $40 \mathrm{mN} / \mathrm{min}$, max. load $20 \mathrm{mN}$ (solid bars). 
of "soft film on hard substrate type" results from microstructures of layer substrate and physical phenomena, such as the indentation size effect or cracking around the indent. ${ }^{73,74}$ The pileup around the indenter can also occur because of relative softness of deposited layer in comparison to the harder silicon wafer. Due to the complexity of the studied materials, it is difficult at this point to clearly interpret the obtained results.

\section{Conclusions}

A series of Schiff bases and their copper(II) complexes derived from ethylenediamine and three different aldehydes were obtained. In four cases, the copper ion exists in square planar $\mathrm{N}_{4}$ geometry distorted from planarity due to coordination with chloride or acetate ions. Only in the case of $\left[\mathrm{Cu}\left(\mathrm{en}(\mathrm{dmbaH})_{2}\right) \mathrm{Cl}_{2}\right]$ the four coordinated copper ion was observed. The optimal parameters of spin coating, resulting in thin layers with equally spread $\mathrm{Cu}$ (II) complexes on Si were: 900, 1100 or $2000 \mathrm{rpm}$ spin rate for $30 \mathrm{~s}$. All the $\mathrm{Cu}$ (II) compounds as thin film layers exhibit luminescence at $\lambda_{\text {ex }}$ between 365 and $382 \mathrm{~nm}$. The emission bands from intraligand $\pi \rightarrow$ $\pi *$ transitions were observed in the range between 462 and $503 \mathrm{~nm}$. The highest intensity of these bands was noticed for the layers with more uniformly placed compounds. The studies on the material properties and the emission of the layer reveal the fact that the complex can be used as optically active materials.

The use of solution-based copper(II) complex and $\mathrm{ZnO}$ precursors provides a facile route to composite organic-inorganic thin layer deposits of well-defined thickness. The structure of these films can be controlled via appropriate choice of precursor and processing conditions. In the case of $\mathrm{ZnO}$ deposition on silicon substrate, uniform, non-continuous coverage but with the island-like aggregates of particles was observed. The mixed layers of copper complex $\left[\mathrm{Cu}(\mathrm{II})\left((\mathrm{en})(4 \mathrm{Him})_{2}\right) \mathrm{Cl}_{2}\right]$ and $\mathrm{ZnO}$ nanoparticles exhibited quenching of the $\mathrm{ZnO}$ fluorescence band at $\lambda_{\mathrm{em}}=$ $440 \mathrm{~nm}$. The analysis of mechanical properties of layers points to decrease in the HIT and EIT values with increasing time of the deposition.

\section{Supplementary Information (SI)}

All additional information pertaining to characterization of the ligands using NMR spectroscopy (figures S1-S7), IR spectra of ligands and complexes (figures S8-S18), electronic data (table S1) are given in the supporting information, available at www.ias.ac.in/ chemsci.

\section{Acknowledgement}

Authors would like to thank the National Science Centre $(\mathrm{NCN})$, Poland for financial support (grant no. 2013/09/B/ST5/03509).

\section{References}

1. Kramer R 1998 Angew. Chem. Int. Ed. 37772

2. Gaggelli E, Kozlowski H, Valensin D and Valensin G 2006 Chem. Rev. 1061995

3. Chetana P R, Srinatha B S, Somashekar M N and Policegoudra R S 2016 J. Mol. Struct. 3521106

4. Rama I and Selvameena R 2015 J. Chem. Sci. 127671

5. Naeimi A, Saeednia S, Yoosefian M, Rudbari H A and Nardo V M 2015 J. Chem. Sci. 1271321

6. Lashanizadegan M and Sarkheil M 2012 J. Serb. Chem. Soc. 771589

7. Amendola V, Fabbrizzi L, Gianelli L, Maggi C and Mangano C 2001 Inorg. Chem. 403579

8. Chen C H and Shi J 1998 Coord. Chem. Rev. 171161

9. Sanchez C, Rozes L, Ribot F, Laberty-Robert C, Grosso D, Sassoye C, Boissiere C and Nicole C 2010 C. R. Chim. 313

10. Brauer B, Zahn D R T, Ruffer T and Salvan G 2006 Chem. Phys. Lett. 432226

11. Ruzgar S and Caglar M 2015 J. Nanoelectr. Optoe. 10 717

12. Che C M, Chan S C, Xiang H F, Chan M C W, Liu Y and Wang Y 2004 Chem. Commun. 1484

13. Chang K H, Huang C C, Liu Y H, Hu Y H, Chou P T and Lin Y C 2004 J. Chem. Soc. Dalton Trans. 1731

14. Ghosh R, Rahaman S H, Lin C N, Lu T H and Ghosh B K 2006 Polyhedron 253104

15. Hu Y, Gao X, Di C, Yang X, Zhang F, Liu Y, Li H and Zhu D 2011 Chem. Mater. 231204

16. Sorar I, Şener M K, Tepehan F Z, Gül A and Koçak M B 2008 Thin Solid Films 5162894

17. Ting-Ting W, He Zhi-Qun, Xiao-Pan Z, Yong-Sheng W, Chun-Xiu Z and Wen-Guan Z 2007 Optoelectron. Lett. 343

18. Qiu W, Hu W, Liu Y, Zhou S, Yu Xu and Zhou D 2001 Sens. Actuators, B $\mathbf{7 5} 62$

19. Sirimanne P M, Rusop M, Shirata T, Soga T and Jimbo T 2003 Mater. Chem. Phys. 80461

20. Jakob A, Rüffer T, Ecorchard P, Walfort B, Körbitz K, Frühauf S, Schulz S E, Gessner T and Lang H 2010 Z. Anorg. Allg. Chem. 6361931

21. Barwiolek M, Szlyk E, Lis J and Muziol T 2011 Dalton Trans. 4011012

22. Barwiolek M, Szlyk E, Surdykowski A and Wojtczak A 2013 Dalton Trans. 4211476

23. Barwiolek M, Szlyk E, Berg A, Wojtczak A, Muziol T and Jezierska J 2014 Dalton Trans. 439924

24. Gupta S K, Joshi A and Kaur M 2010 J. Chem. Sci. 12257

25. Lin B, Fu Z and Jia Y 2001 Appl. Phys. Lett. 79943

26. Drmosh Q A, Rao S G, Yamani Z H and Gonda M A 2013 Appl. Surf. Sci. 270104

27. Khanlary M R, Hajinorozi A and Baghshahi S 2015 J. Inorg. Organomet. Polym. 251521 
28. Heredia E, Bojorge C, Casanova J, Cánepa H, Craievich A and Kellermann G 2014 Appl. Surf. Sci. 31719

29. Reddy A J, Kokila M K, Nagabhushana H, Rao J L, Shivakumara C, Nagabhushana B M and Chakradhar R P S 2011 Spectrochim. Acta Part A 8159

30. Singh A K, Viswanath V and Janu V C 2009 J. Lumin. 129874

31. Xin M, Hu L Z, Liu D-P and Yu N-S 2014 Superlatt. Microstr. 74234

32. Sharma K P, Kumar M and Pandey A C 2011 J. Nanopart Res. 131629

33. Chow L, Lupan O, Chai G, Khallaf H, Ono L K, Cuenya B R, Tiginyanu I M, Ursaki V V, Sontea V and Schulte A 2013 Sens. Actuators, A 189399

34. Oliver W C and Pharr G M 1992 J. Mater. Res. 71564

35. Gullotti M, Pasini A, Fantucci P, Ugo R and Gillard D 1972 Gazz. Chim. Ital. 102855

36. Smith H E, Neergaard J R, Burrows E P and Chen F M 1974 J. Am. Chem. Soc. 962908

37. Lever A B P 2006 In Inorganic Electronic Spectroscopy (Hoboken: Wiley-Interscience)

38. Roy S, Choubey S, Bhar K, Khan S, Mitra P and Ghosh B K 2013 J. Mol. Struct. 1051328

39. Rogness D C, Markina N A, Waldo J P and Larock R C 2012 J. Org. Chem. 772743

40. Ogden M D, Meier G P and Nash K L 2012 J. Solution Chem. 411

41. Abherve A, Clemente-Juan J M, Coronado M, Boonmak E J and Youngme S 2014 New J. Chem. 38(5) 2105

42. Khalaji A D, Mighani H, Gholinejad M, Grivani G, Akerdi S, Fejfarova J K and Dusek M 2013 J. Struct. Chem. 54774

43. Günther H 2013 In NMR Spectroscopy Basic Principles, Concepts, and Applications in Chemistry (New York: John Wiley)

44. Baillie M J, Brown D H, Moss K C and Sharp D W 1968 J. Chem. Soc. A 123110

45. Nakamoto K 2009 In Infrared and Raman Spectra of Inorganic and Coordination Compounds $6^{\text {th }}$ ed. (New York: John Wiley)

46. Deacon G B and Phillips R J 1980 Coord. Chem. Rev. 33227

47. Morzyk-Ociepa B and Michalska D 2003 Spectrochim. Acta Part A 591247

48. Cotton F A and Wilkinson G 1988 In Advanced Inorganic Chemistry $5^{\text {th }}$ ed (New York: John Wiley)

49. R D Gillard and J A Mc Cleverty (Eds.) 1987 Comprehensive Coordination Chemistry (Oxford: Pergamon) Vol. 2 p. 716
50. Bitenc M, Marinšek M and Orel Z C 2008 J. Eur. Ceram. Soc. 282915

51. Hsieh Ch-H 2007 J. Chin. Chem. Soc. 5431

52. Singh S, Barick K C and Bahadur D 2013 J. Mater. Chem. A 13325

53. Anžlovar A, Kogej K, Orel C Z and Žigon M 2014 Cryst. Growth Des. 144262

54. Jakob A, Rüffer T, Schmidt H, Djiele P, Körbitz K, Ecorchard P, Haase T, Köhse-Hoinghaus K, Frühauf S, Wächtler T, Schulz S, Gessner T and Lang H 2010 Eur. J. Inorg. Chem. 2975

55. Komino T, Matsuda M and Tajima H 2009 Thin Solid Films $\mathbf{5 1 8} 688$

56. Bin W, Li Z, Zuo X, Wu Y, Wang X, Chen Z, He Ch, Duan W and Gao J 2010 Sens. Actuators, B 149362

57. Wang B, Chen Z, Zuo X, Wu Y, He Ch, Wang X and Li Z 2011 Sens. Actuators, B 1601

58. Wang B, Zhou X, Wu Ch, He Ch and Zuo X 2012 Sens. Actuators, B 161498

59. Babikier M, Wang D, Wang J, Li Q, Sun J, Yan Y, Yu Q and Jiao S 2014 Nanoscale Res. Lett. 9199

60. Kundu T K, Karak N, Barik P and Saha S 2011 Int. J. Soft Comput. Eng. (IJSCE) 119

61. Chen S J, Liu Y C, Shao C L, Mu R, Lu Y M, Zhang J Y, Shen D Z and Fan X W 2005 Adv. Mater. 17586

62. Zhang D H, Wang Q P and Xue Z Y 2003 Appl. Surf. Sci. 20720

63. Du G H, Xu F, Yuan Z Y and Tendeloo G V 2006 Appl. Phys. Lett. 88243101

64. Park J H, Muralidharan P and Kim D K 2009 Mater. Lett. 631019

65. Li Y, Xu L, Li X, Shen X and Wang A 2010 Appl. Surf. Sci. 2564543

66. Lakowicz J R 2006 In Principles of Fluorescence Spectroscopy $3^{\text {th }}$ ed. (New York: Springer)

67. Chen X-M and Liu G-F 2002 Chem. Eur. J. 84811

68. Varnes A W, Dadson R B and Wehry E L 1972 J. Am. Chem. Soc. 94946

69. Kemlo J A and Sheperd T M 1977 Chem. Phys. Lett. 47158

70. Hess P 1996 Appl. Surf. Sci. 106429

71. Kim M T 1996 Thin Solid Films 28313

72. Chang L and Zhang L C 2009 Acta Mater. 572148

73. Yoon H-K and Yu Y-S 2005 Int. Symp. on Electronics Materials and Packaging EMAP 11-14.12.2005, 2005 169

74. Korsunsky A M, McGurk M R, Bull S J and Page T F 1998 Surf. Coat. Technol. 99171 